\title{
ANALISIS POSTUR KERJA PADA PEMBUATAN RUMAH BONEKA DENGAN METODE RAPID ENTIRE BODY ASSESSMENT
}

\author{
Tiara Mardi ${ }^{1}$, Surya Perdana ${ }^{2}$ \\ Program Studi Teknik Industri, Universitas Indraprasta PGRI \\ tiaramardi.04@gmail.com ${ }^{1}$, suryaperdana.st.mm@gmail.com ${ }^{2}$
}

\begin{abstract}
Abstrak
PT. X adalah perusahaan yang bergerak dibidang pembuatan rumah boneka. Berbagai tahap proses produksi pada setiap stasiun kerja dilakukan setiap hari dilantai dengan posisi jongkok dalam jangka waktu yang lama. Terdapat tujuh stasiun kerja yaitu stasiun kerja pembuatan pola, pemotongan pola, perakitan pola, pendempulan, pengamplasan, pengecatan dan pemasangan aksesoris. Penelitian ini bertujuan untuk mengetahui nilai resiko postur kerja operator dan memberikan usulan perbaikan pada stasiun kerja yang sangat beresiko. Metode yang digunakan pada penelitian ini adalah metode Rapid Entire Body Assessment (REBA), berdasarkan nordic questionaire masalah keluhan terdapat di punggung, pinggang, pinggul, tangan kanan dan kaki. Hasil pengumpulan dan pengolahan data menunjukkan bahwa resiko cedera dengan sistem kerja aktual berdasarkan REBA score adalah level resiko tinggi, yang memiliki nilai level resiko tertinggi yaitu pada stasiun kerja pendempulan dengan skor reba 9 untuk bagian kiri dan 8 untuk bagian kanan. Namun, dengan usulan perbaikan sistem kerja dengan menggunakan kursi dan meja kerja dihasilkan penurunan resiko cedera dengan skor REBA rendah, yaitu rata-rata memiliki skor REBA 5 untuk semua stasiun kerja perbaikan. Hal ini menunjukkan bahwa usulan perbaikan sistem kerja sangat dibutuhkan untuk mengurangi resiko kerja dalam pembuatan rumah boneka.
\end{abstract}

Kata Kunci: Rapid Entire Body Assessment (REBA), Musculoskeletal Disorders, Nordic Questionaire, Work Station, Level of Risk

\begin{abstract}
PT. $X$ is a company engaged in the manufacture of the doll house. Its various daily production processes in each work station are performed on the floor by squatting for long hours. There are seven work stations, namely pattern making, pattern cutting, pattern assembly, caulking, sanding, painting and accessory installation. The study aims to know the risk level of working posture of operators and to suggest improvements to very risky work stations. The method used in this research is Rapid Entire Body Assessment (REBA) based on nordic questionaire on pains suffered in the back, waist, hip, right hand and foot. From the results of the collection and processing of the data, the risk of injury in an actual working system based on REBA score shows a high risk level, with the highest risk level is in caulking working station of 9 for the left side and 8 for the right side. Further, the suggested working system improvement using a chair and table results in a decrease in the risk of injury with low REBA score, the average of which is 5 for all improved work stations. It shows that the suggested working system improvement is really necessary to reduce the work risks during the doll house production.

Keywords: Rapid Entire Body Assessment (REBA), Musculoskeletal Disorders, Nordic Questionaire, Work Station, Level of Risk
\end{abstract}

\section{PENDAHULUAN}

Tempat kerja, faktor kerja manusia mengandung potensi bahaya yang tinggi sehingga diperlukan suatu upaya pencegahan agar tidak terjadi kecelakaan dan penyakit akibat postur kerja yang tidak sesuai [9]. Fasilitas kerja merupakan komponen yang berhubungan langsung dengan manusia dimana rancangan fasilitas kerja yang baik sangat diperlukan sesuai dengan kemampuan manusia untuk berinteraksi dengan fasilitas kerjanya [1].

Tenaga kerja yang melakukan pekerjaan secara manual beresiko mengalami gangguan muskuloskeletal, yaitu cedera pada bagian otot, urat syaraf, urat daging, tulang, persendian tulang, tulang rawan 
yang disebabkan oleh aktivitas kerja. postur kerja yang janggal adalah penyebab utama terjadinya gangguan muskuloskeletal. Beberapa contoh yang tergolong dalam postur kerja janggal yaitu: meraih benda ke belakang, memutar anggota badan, melakukan pekerjaan dengan ketinggian melebihi kepala, pergerakan pergelangan tangan dengan menekuk, posisi berlutut, posisi membungkuk, gerak maju dan mundur, gerakan membungkuk, serta posisi jongkok [5].

Jika otot tubuh menerima beban statis dari efek kerja secara berulang-ulang dan diterima otot tubuh dalam jangka waktu yang cukup lama, maka akan menyebabkan terjadi keluhan pada tubuh berupa kerusakan pada sendi, pada ligamen dan tendon. Selanjutnya faktor-faktor yang menyebabkan keluhan muskuloskeletal adalah peregangan pada otot tubuh yang berlebihan, aktivitas yang dikerjakan secara berulang, sikap kerja yang tidak alamiah, penyebab sekunder lain dan penyebab kombinasi [4].

Secara garis besar keluhan otot dapat dikelompokan menjadi dua, yaitu: Keluhan yang sifatnya sementara (reversible), yaitu merupakan keluhan pada bagian otot yang terjadi akibat otot menerima beban yang statis, keluhan ini akan segera hilang jika pemberian beban dihentikan, keluhan yang kedua merupakan keluhan yang menetap (persistent), yaitu merupakan keluhan pada bagian otot yang sifatnya menetap. Meskipun pemberian beban kerja pada bagian otot tubuh sudah dihentikan, namun rasa sakit yang dialami pada bagian otot tubuh masih terus berlanjut [8].

Ergonomi merupakan kajian interaksi antara manusia dan mesin, serta faktorfaktor yang mempengaruhinya. Tujuannya adalah untuk meningkatkan kinerja sistem secara keseluruhan [6]. Ergonomi merupakan suatu ilmu terapan yang mampu menyelaraskan (fitting) suatu stasiun kerja dan jenis pekerjaan yang dilakukan dengan kapabilitas dari seorang pekerja itu sendiri [3].

Rapid Entire Body Assesment (REBA) merupakan metode yang dikembangkan pada bidang ergonomi. REBA (Rapid Entire Body Assessment) adalah merupakan metode yang digunakan dalam analisa postur kerja. Metode REBA dapat digunakan untuk menilai postur tubuh seperti: bagian leher, bagian punggung, bagian lengan, bagian pergelangan tangan, dan bagian kaki seorang pekerja [7]. Selain itu metode ini juga dipengaruhi faktor coupling, beban external yang dialami oleh tubuh serta aktivitas pekerja [9].

Langkah-langkah sistematis untuk melakukan analisis postur kerja menggunakan metoda Rapid Entire Body Assessment (REBA), adalah:

1. Pengambilan postur tubuh pekerja dengan menggunakan video atau foto.

2. Penentuan sudut-sudut dari postur tubuh pekerja, dibagi menjadi dua bagian yaitu: a) Bagian A yang terdiri dari batang tubuh (punggung), leher dan kaki; b) Bagian B yang terdiri dari lengan atas, lengan bawah, dan pergelangan tangan

3. Penentuan berat benda yang diangkat.

4. Perhitungan skor Rapid Entire Body Assessment (REBA) [2].

PT $\mathrm{X}$ adalah sebuah perusahaan industri kecil menengah yang bergerak dalam pembuatan rumah boneka. Proses produksi masih dilakukan secara sederhana dan banyak dilakukan secara manual. Proses produksi di setiap stasiun dilakukan di lantai, di mana operator hampir selalu berjongkok ataupun duduk selama mereka melakukan pekerjaannya. Selain itu terdapat 4 orang pekerja yang memiliki keterbatasan fisik dan harus bekerja di kursi roda. Posisi kerja ini, sangat mengurangi kenyamanan pekerja dan berpotensi menimbulkan penyakit apabila terus dibiarkan dalam jangka waktu yang 
lama. Kegiatan produksi tersebut dilakukan sekitar $9 \mathrm{jam} / \mathrm{hari}$. Aktivitas material handling juga selalu dilakukan secara manual.

Pada proses pembuatan rumah boneka ini terlihat bahwa posisi kerja yang dilakukan oleh pekerja sering kali dalam posisi yang tidak ergonomis, hal ini didukung oleh penelitian pendahuluan yang telah dilakukan. Berdasarkan penelitian pendahuluan yang telah dilakukan dengan penyebaran Nordic Questionnaire, diketahui bahwa para pekerja sering merasakan sakit (pegal/nyeri) terutama pada bagian punggung, pinggang, pinggul dan pantat, pergelangan tangan kanan, tangan kanan, betis kiri kanan, lutut kiri kanan dan kedua bagian kaki.

Tujuan dalam penelitian ini adalah mengurangi resiko cedera yang dialami operator dan Memberikan usulan terhadap posisi kerja yang ergonomis.

\section{METODOLOGI PENELITIAN}

Penelitian ini dilakukan di PT. X yang berlokasi di Jl. RS Fatmawati, Pondok Labu, Jakarta Selatan. Objek penelitian ini adalah para pekerja pembuatan rumah boneka.

Kegiatan yang akan diamati di sini adalah kegiatan pembuatan rumah boneka. Studi lapangan yang dilakukan pada penelitian ini adalah sebagai berikut :

Observasi dengan melakukan pengamatan langsung pada objek yang diteliti. Observasi ini bertujuan untuk mendapatkan data proses pembuatan produk, foto-foto pekerja dalam bekerja dan keluhan yang dialami pekerja.

Wawancara (Interview) dilakukan dengan cara menggali informasi kondisi awal mengenai aktivitas kerja, biodata pekerja, aktivitas jam kerja, lama bekerja, keluhan, proses produksi serta ketidaknyamanan pekerja pada saat melakukan aktivitas pembuatan rumah boneka.

Kuesioner dengan cara membagikan Nordic Questionnaire pada masing-masing pekerja untuk penilaian terhadap resiko kerja yang berhubungan dengan gangguan otot ditempat kerja, guna mengetahui masalah yang dialami oleh para pekerja pada saat bekerja terus-menerus.

\section{HASIL DAN PEMBAHASAN}

Stasiun kerja pendempulan dibagi menjadi 3 proses pekerjaan, yaitu proses pengambilan dempul, pengambilan body dan pendempulan body. Proses pengambilan dempul dan proses pengambilan body dilakukan pekerja dengan posisi berdiri, sedangkan untuk proses pendempulan dilakukan pekerja dengan posisi jongkok. Pada proses pendempulan ini merupakan suatu proses tersulit dari seluruh proses yang telah dilewati pekerja, Kesulitan tersebut harus tetap dijalani pekerja karena proses ini adalah proses penentuan kesempurnaan dari hasil akhir rumah boneka. Semakin baik dan semakin detail kerja para pekerja dalam proses mendempul ini dijamin hasil akhir dari pengecatan akan sempurna. Proses ini dilakukan dengan posisi jongkok dan membutuhkan waktu sekitar 30 menit/produk.

\section{Sistem Kerja}

PT. X bekerja setiap hari secara berkelanjutan selama 9 jam per hari, dengan perincian jadwal pekerja sebagai berikut :

Tabel 1. Jadwal kerja pekerja

\begin{tabular}{ccc}
\hline Hari & Jam Kerja & Jam Istirahat \\
\hline Senin-Sabtu & $08.00-17.00$ & $12.00-13.00$ \\
Minggu & $10.00-18.00$ & $12.00-13.00$ \\
\hline
\end{tabular}

\section{Nordic Questionaire}

Nordic Questionaire adalah kuesioner yang dipergunakan sebagai alat untuk mengetahui ketidaknyamanan yang dirasakan para pekerja, kuesioner ini paling sering digunakan karena sudah 
terstandarisasi dan tersusun rapi. Nordic Questionaire menggunakan gambar anggota tubuh manusia dan anggota tubuh tersebut dibagi menjadi 9 bagian utama, yaitu: bagian leher, bahu, punggung bagian atas, siku, punggung bagian bawah, bagian pergelangan tangan/tangan, pinggang, bagian lutut, dan Tumit/kaki.

Tabel 2. Rekapitulasi Hasil Tingkat Keluhan pada Proses Pembuatan Rumah Boneka

\begin{tabular}{|c|c|c|c|c|c|c|c|}
\hline \multirow{2}{*}{$\mathrm{NO}$} & \multirow{2}{*}{ JENIS KELUHAN } & \multicolumn{4}{|c|}{ TINGKAT KELUHAN } & \multirow{2}{*}{\multicolumn{2}{|c|}{ Keterangan: }} \\
\hline & & TS & KS & $\mathrm{S}$ & $\mathrm{SS}$ & & \\
\hline 0 & Sakit/kaku di leher bagian atas & 7 & 1 & & & & - \\
\hline 1 & Sakit/kaku di leher bagian bawah & 4 & 4 & & & & akit \\
\hline 2 & Sakit di bahu kiri & 4 & 4 & & & $\begin{array}{l}4 \\
\mathrm{c} \\
\mathrm{c}\end{array}$ & $=\mathrm{Sak} 1 \mathrm{l}$, \\
\hline 3 & Sakit di bahu kanan & 3 & 5 & & & & \\
\hline
\end{tabular}

\begin{tabular}{|l|l|l}
\hline 4 & Sakit pada lengan atas kiri & 3 \\
\hline
\end{tabular}

\begin{tabular}{|l|l|l|l|l|l|}
5 & Sakit di punggung & & 2 & 6 & \\
\hline 6 & Sakit pada & & 4 & 2 & \\
\hline
\end{tabular}

6 Sakit pada lengan atas kanan

\begin{tabular}{|l|l|l|l|}
7 & Sakit pada pinggang & 4 & 2 \\
\hline 8 & Sakit pada pinggu & 2 & 6 \\
\hline
\end{tabular}

8 Sakit pada pinggul

9 Sakit pada pantat

10 Sakit pada siku kiri

11 Sakit pada siku kanan

12 Sakit pada lengan bawah kiri

13 Sakit pada lengan bawah kanan

14 Sakit pada pergelangan tangan kiri

15 Sakit pada pergelangan tangan kanan

16 Sakit pada tangan kir

17 Sakit pada tangan kanan

18 Sakit pada paha kiri

19 Sakit pada paha kanan

20 Sakit pada lutut kiri

21 Sakit pada lutut kanan

22 Sakit pada betis kiri

23 Sakit pada betis kanan

24 Sakit pada pergelangan kaki kiri

25 Sakit pada pergelangan kaki kanan

26 Sakit pada kaki kiri

27 Sakit pada kaki kanan

\section{Metode REBA}

Pengumpulan data dengan menggunakan metode REBA digunakan untuk menilai posisi tubuh pekerja di PT $X$. REBA merupakan suatu perhitungan seluruh bagian tubuh para pekerja, REBA juga sering digunakan dalam perhitungan posisi kerja dan digunakan untuk mengetahui perbaikan posisi tubuh pekerja. Perhitungan REBA dilakukan dengan metode langsung melihat pekerja melakukan kegiatan dan dengan cara melihat hasil foto dari para pekerja tersebut. 


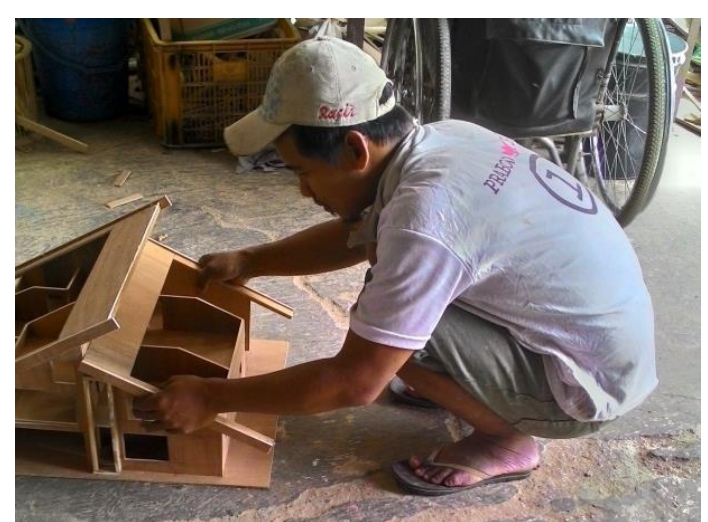

Gambar 1. Pengambilan Body (Proses Pendempulan Body)

$\begin{array}{ll}\text { Neck } & : 27^{\circ} \\ \text { Trunk } & : 57^{\circ} \\ \text { Leg } & : 135^{\circ} \\ \text { Upper Arm } & : 44^{\circ} \text { (kanan), } 45^{\circ} \text { (kiri) } \\ \text { Lower Arm } & : 40^{\circ} \text { (kanan), } 39^{\circ} \text { (kiri) } \\ \text { Wrist } & : 14^{\circ} \text { (kanan), } 13^{\circ} \text { (kiri) }\end{array}$

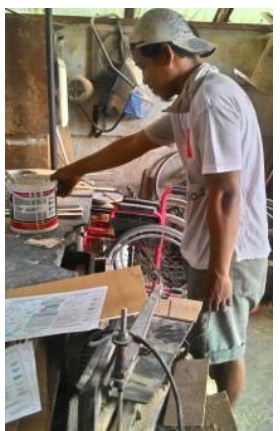

$\begin{array}{ll}\text { Neck } & : 24^{\circ} \\ \text { Trunk } & : 18^{\circ} \\ \text { Leg } & : 8^{\circ} \\ \text { Upper Arm } & : 76^{\circ} \text { (kanan), } 0^{\circ} \text { (kiri) } \\ \text { Lower Arm } & : 82^{\circ} \text { (kanan), } 0^{\circ} \text { (kiri) } \\ \text { Wrist } & : 14^{\circ} \text { (kanan), } 11^{\circ} \text { (kiri) }\end{array}$

Gambar 3. Proses Pendempulan Body

Neck $\quad: 20^{\circ}$

Trunk $: 15^{\circ}$

Leg $\quad: 138^{\circ}$

Upper Arm $\quad: 25^{\circ}$ (kanan), $85^{\circ}$ (kiri)

Lower Arm $\quad: 78^{\circ}$ (kanan), $97^{\circ}$ (kiri)

Wrist $\quad: 14^{\circ}$ (kanan), $11^{\circ}$ (kiri)

Gambar 2. Pengambilan Dempul

(Proses Pendempulan Body)

Tabel 3. Nilai Bagian Tubuh Pada Proses Pendempulan Body

\begin{tabular}{|c|c|c|c|c|c|c|c|c|c|c|}
\hline \multirow{3}{*}{ NO } & \multirow{3}{*}{ PEKERJAAAN } & \multicolumn{9}{|c|}{ BAGIAN } \\
\hline & & \multirow{2}{*}{ Leher } & \multirow{2}{*}{ Punggung } & \multirow{2}{*}{ Kaki } & \multicolumn{2}{|c|}{ Lengan Atas } & \multicolumn{2}{|c|}{ Lengan Bawah } & \multicolumn{2}{|c|}{ Pergelangan Tangan } \\
\hline & & & & & $\mathrm{L}$ & $\mathrm{R}$ & $\mathrm{L}$ & $\mathrm{R}$ & $\mathrm{L}$ & $\mathrm{R}$ \\
\hline 1 & Pengambilan Dempu & 2 & 2 & 1 & 1 & 3 & 1 & 1 & 1 & 1 \\
\hline 2 & Pengambilan Bodv & 2 & 3 & 1 & 2 & 2 & 2 & 2 & 1 & 1 \\
\hline 3 & Pendempulan $B o d v$ & 2 & 3 & 4 & 3 & 2 & 2 & 1 & 1 & 1 \\
\hline
\end{tabular}

\section{Posisi Kerja Setelah Perbaikan}

Pada penelitian ini, peneliti mengusulkan kepada semua pekerja untuk menggunakan fasilitas berupa meja dan kursi dalam melakukan aktivitasnya, fasilitas ini untuk mengurangi kelelahan para pekerja pada
PT.X. Hasil foto dari posisi perbaikan dapat dilihat pada gambar 4 . 


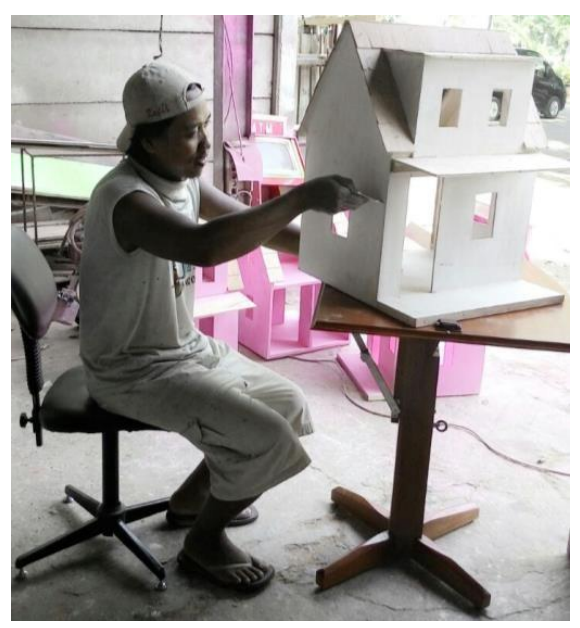

Gambar 4. Perbaikan Postur Kerja dengan Menggunakan meja dan Kursi Pada Proses Pendempulan

$\begin{array}{ll}\text { Neck } & : 3^{\circ} \\ \text { Trunk } & : 5^{\circ} \\ \text { Leg } & : 104^{\circ} \\ \text { Upper Arm } & : 88^{\circ}(\text { kanan }), 82^{\circ} \text { (kiri) } \\ \text { Lower Arm } & : 97^{\circ}\left(\text { kanan), } 81^{\circ} \text { (kiri) }\right.\end{array}$

\section{Pengolahan Data}

Data-data dalam penelitian ini diperoleh melalui cara langsung dan tidak langsung. Setelah mendapatkan data dari penelitian dan pengamatan, maka langkah selanjutnya adalah melakukan pengolahan dari data yang diperoleh tersebut. Data yang diolah meliputi: data Nordic Questionaire pekerja dan perhitungan metode REBA.

\section{Nordic Questionaire}

Untuk keluhan-keluhan yang terjadi pada Standard Nordic Questionaire selanjutnya dilakukan rekapitulasi dengan menjumlahkan seluruh keluhan yang sejenis, lalu selanjutnya dibuat persentase dari seluruh pekerja yang ada. Hasil rekapitulasi Standard Nordic Questionaire dapat dilihat pada Tabel 4.

\section{Tabel 4. Hasil Rekapitulasi Standard Nordic Questionaire}

\begin{tabular}{|c|c|c|c|l|}
\hline No & Jenis Keluhan & $\begin{array}{c}\text { Jumlah } \\
\text { Pekerja }\end{array}$ & $\begin{array}{c}\text { Persentase Dari Jumlah Pekerja } \\
\text { (Jumlah keluhan pekerja/Total } \\
\text { operator x 100\%) }\end{array}$ & \multicolumn{1}{|c|}{ Keterangan Proses Kerja } \\
\hline 1 & $\begin{array}{c}\text { Sakit pada } \\
\text { pinggang }\end{array}$ & 6 & $75 \%$ & $\begin{array}{l}\text { Pembuatan pola, pendempulan, pengecatan, perakitan, } \\
\text { pengamplasan, pemotongan, perakitan (aksesoris), } \\
\text { pengamplasan (aksesoris) }\end{array}$ \\
\hline 2 & $\begin{array}{c}\text { Sakit pada } \\
\text { lutut kiri }\end{array}$ & 3 & $37 \%$ & $\begin{array}{l}\text { Pembuatan pola, pendempulan, pengecatan, perakitan } \\
\text { dan pengamplasan }\end{array}$ \\
\hline 3 & $\begin{array}{c}\text { Sakit pada } \\
\text { lutut kanan }\end{array}$ & 3 & $37 \%$ & $\begin{array}{l}\text { Perakitan, pengamplasan, pengecatan, pembuatan pola } \\
\text { dan pendempulan }\end{array}$ \\
\hline 4 & $\begin{array}{c}\text { Sakit pada } \\
\text { betis kiri }\end{array}$ & 4 & $50 \%$ & $\begin{array}{l}\text { Pembuatan pola, pendempulan, pengecatan, perakitan, } \\
\text { pengamplasan dan pemasangan aksesoris }\end{array}$ \\
\hline 5 & $\begin{array}{c}\text { Sakit pada } \\
\text { betis kanan }\end{array}$ & 4 & $50 \%$ & $\begin{array}{l}\text { Pembuatan pola, pendempulan, pengamplasan, } \\
\text { pengecatan, perakitan dan pemasangan aksesoris }\end{array}$ \\
\hline 6 & $\begin{array}{c}\text { Sakit pada kaki } \\
\text { kiri }\end{array}$ & 4 & $50 \%$ & $\begin{array}{l}\text { Pembuatan pola, pendempulan, pengecatan, perakitan, } \\
\text { pengamplasan dan pemasangan aksesoris }\end{array}$ \\
\hline 7 & $\begin{array}{c}\text { Sakit pada kaki } \\
\text { kanan }\end{array}$ & 4 & $50 \%$ & $\begin{array}{l}\text { Pembuatan pola, pendempulan, pengecatan, perakitan, } \\
\text { pengamplasan dan pemasangan aksesoris }\end{array}$ \\
\hline
\end{tabular}

\section{REBA Score}

Pengolahan data metode REBA terdiri dari dua cara, pertama menggunakan data
REBA worksheet untuk mengukur postur kerja dengan beberapa tahap, tahap 1 membagi pengamatan bagian tubuh 
operator kedalam 2 grup, yaitu grup A yang terdiri atas leher (neck), punggung (trunk) dan kaki (leg). Grup B yang terdiri atas bagian lengan atas (upper arm), bagian lengan bawah (lower arm) dan bagian pergelangan tangan (wrist), serta mengukur beban (load/force) dan skor aktivitas. Tahap 2 menilai setiap postur operator menggunakan REBA ke dalam skor A dan skor B. tahap 3 menentukan skor akhir REBA dari hasil kombinasi perhitungan skor A dan skor B.
Tahap 4 menentukan action level/level tindakan dari postur kerja operator.

Cara kedua dengan menentukan postur kerja yang tidak ergonomis berdasarkan perhitungan skor REBA dan penentuan action level/level tindakan.

Hasil perhitungan REBA untuk proses pendempulan dapat dilihat pada Gambar 5 - Gambar 7. Dan rekapitulasi hasil perhitungan posisi kerja pada proses pendempulan dapat dilihat pada tabel 5.

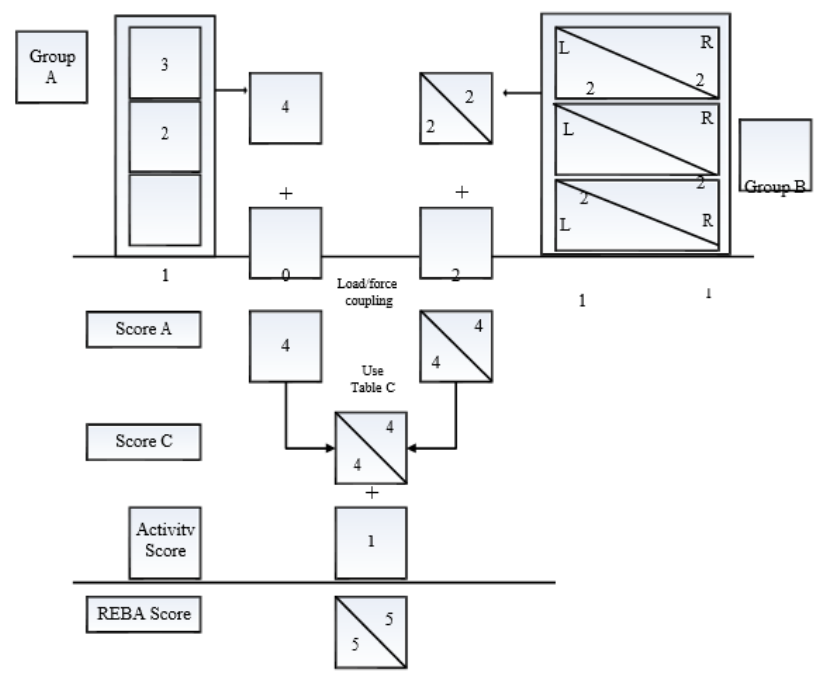

Gambar 5. Perhitungan Skor REBA Pengambilan Body (Proses Pendempulan Body)

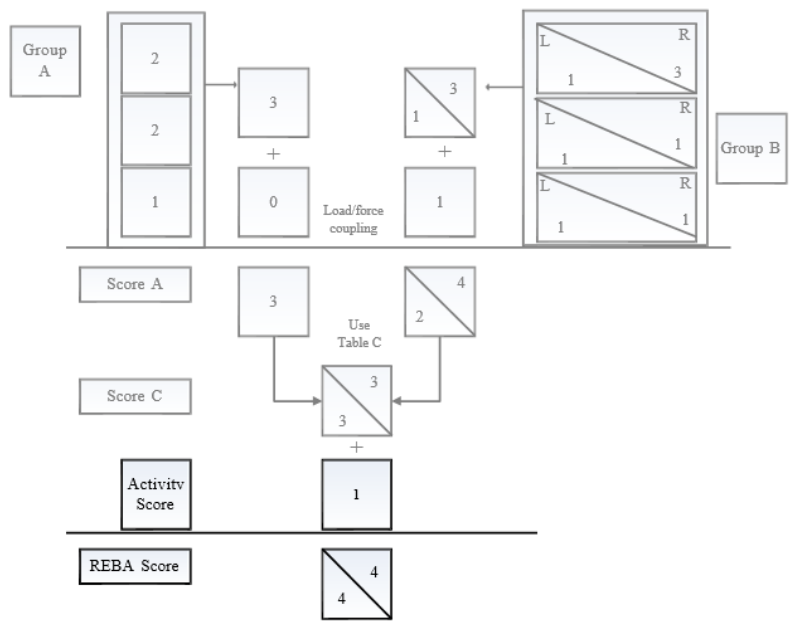

Gambar 6. Perhitungan Skor REBA Pengambilan Dempul (Proses Pendempulan Body) 


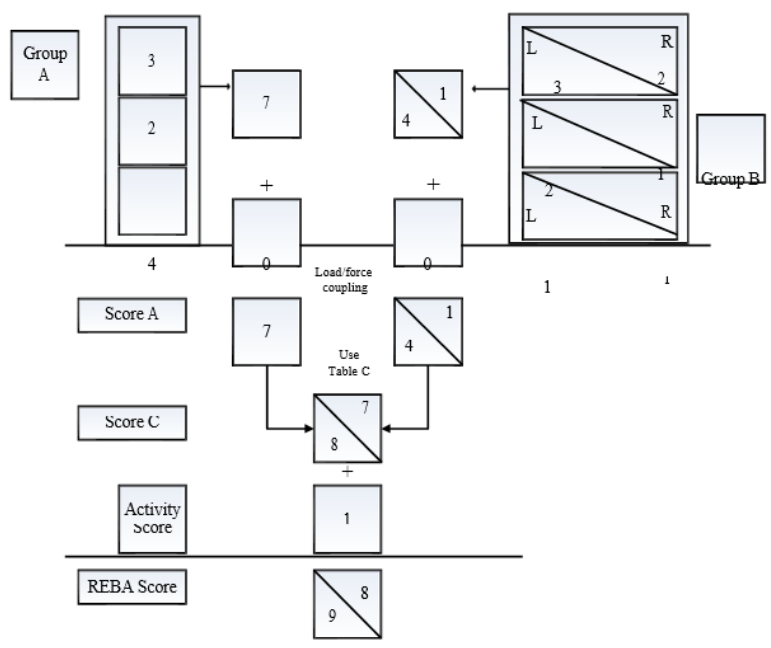

Gambar 7. Perhitungan Skor REBA Proses Pendempulan Body

Tabel 5. Rekapitulasi Perhitungan REBA Pada Proses Pendempulan

\begin{tabular}{|c|c|c|c|c|}
\hline NO & PEKERJAAN & SKOR REBA & LEVEL & KETERANGAN \\
\hline 1 & Pengambilan Body & 5 & 2 & $\begin{array}{l}\text { Mungkin perlu tindakan } \\
\text { perbaikan }\end{array}$ \\
\hline 2 & Pengambilan Dempul & 4 & 2 & Perlu tindakan perbaikan \\
\hline 3 & Pendempulan Body & 9 & 3 & $\begin{array}{l}\text { Perlu tindakan perbaikan } \\
\text { segera }\end{array}$ \\
\hline
\end{tabular}

\section{Analisis Standard Nordic Questionaire}

Dari hasil pengolahan data dengan menyebar kuesioner, maka dapat dilakukan analisis terhadap permasalahan yang ada. Hasil Standard Nordic Questionaire yang telah dilakukan terhadap 8 orang pekerja menunjukkan bahwa, keluhan yang paling banyak dirasakan sakit oleh para pekerja adalah akibat posisi kerja dengan cara jongkok. Posisi kerja dengan cara jongkok terlalu lama bisa menjadikan punggung bungkuk. Penilaian Nordic Questionaire adalah sebagai berikut :

a. Sakit pada punggung yang dirasakan oleh 6 orang pekerja atau dengan persentase $75 \%$. Sakit pada pinggang yang dirasakan oleh 6 orang pekerja atau dengan persentase $75 \%$. Rasa sakit pada punggung dan pinggang sering dirasakan para pekerja apabila melakukan posisi kerja dengan cara membungkuk dalam waktu yang cukup lama. Pada posisi yang membungkuk akan terjadi penyempitan jarak antar ruas tulang belakang yang akan mengakibatkan terjadinya kompresi yang berlebihan pada bantalan antar ruas (invertebral disc). Akibat kompresi ini, bantalan menekan serabut syaraf yang menyebabkan rasa nyeri di sekitar tulang belakang. Selain itu berakibat tertekannya otot pada bagian perut, sudut yang terlalu sempit dapat mengakibatkan terhambatnya peredaran darah di sekitar kaki dan tungkai bagian bawah.

b. Sakit pada lengan atas kanan yang dirasakan oleh 2 orang pekerja atau dengan persentase $25 \%$. Sakit pada pergelangan tangan kanan, yang dirasakan oleh 3 pekerja atau dengan persentase $37 \%$. Sakit pada tangan kanan 
yang dirasakan oleh 3 orang atau dengan persentase $37 \%$. Rasa sakit pada bagian pergelangan tangan kanan dan tangan kanan dirasakan pekerja saat menggunakan peralatan pemotongan dalam waktu yang lama. Pada proses ini pekerja menggunakan alat pemotongan dan pekerja harus fokus dalam mengerjakan pekerjaan ini. Pada saat proses ini bagian tubuh pekerja mengalami getaran selama bekerja dikarenakan alat yang digunakan.

c. Sakit pada pinggul yang dirasakan oleh 4 orang pekerja atau dengan persentase $50 \%$. Rasa sakit pada pantat yang dirasakan oleh 4 orang pekerja atau dengan persentase $50 \%$. Rasa sakit pada pinggul dan pantat banyak dirasakan oleh pekerja yang mengalami keterbatasan fisik.

d. Sakit pada lutut kiri dan lutut kanan yang masing-masing dirasakan oleh 3 orang atau dengan persentase $37 \%$. Sakit pada betis kiri dan betis kanan yang masing-masing dirasakan oleh 4 orang pekerja atau dengan persentase 50 $\%$. Sakit pada kaki kiri dan kaki kanan yang masing- masing dirasakan oleh 4 orang pekerja atau dengan persentase $50 \%$. Pada bagian lutut, betis dan kaki dirasakan sakit oleh para pekerja karena pekerja terlalu lama melakukan tugasnya dengan cara berjongkok. Postur kerja jongkok dalam banyak hal tidak direkomendasikan sebagai postur kerja yang sehat karena beberapa alasan antara lain yaitu tidak semua orang mampu melakukan postur jongkok karena adanya keterbatasan fisik. Untuk mendapatkan kesetimbangan tubuh yang stabil, pada posisi tubuh yang jongkok mengakibatkan gambar kurva tulang berubah menjadi membungkuk (overflexed).

Hubungan antara postur kerja dengan cedera otot adalah terjadinya cidera otot disebabkan karena postur kerja yang salah. Cedera pada bagian lutut kerap terjadi pada postur kerja dimana bagian paha dan betis berhimpit pada saat jongkok (overflexed knee) dalam rentang waktu yang cukup lama.

\section{Analisis Posisi Kerja Berdasarkan Metode Rapid Entire Body Assessment (REBA)}

Pada proses pendempulan, aktivitas tersebut dibagi kedalam masing-masing pekerjaan untuk memudahkan proses penilaian. Pembagian masing-masing pekerjaan ini berbeda- beda untuk tiap proses aktivitas karena tiap pekerja memiliki sikap kerja yang berbeda untuk tiap aktivitas.

Pada stasiun kerja pendempulan dengan level 3 resiko tinggi yaitu perlu tindakan perbaikan segera untuk mengurangi resiko kerja, cara kerja di stasiun kerja ini adalah mendempul dengan sikap kerja jongkok secara teru-menerus sehingga kalau dibiarkan terlalu lama resiko yang diterima operator akan semakin besar. Bagian tubuh yang mendapatkan nilai tertinggi adalah pada bagian punggung, kaki dan lengan atas bagian kiri. Masingmasing bagian tubuh tersebut mendapatkan nilai 3 untuk bagian punggung, 4 untuk kedua bagian kaki dan 3 untuk lengan atas bagian kiri.

\section{Analisis Hubungan Antara Nordic Questionaire dengan Metode REBA}

Sebagian besar pekerja pada PT. X berada pada kategori posisi kerja yang beresiko tinggi. Hasil tabulasi antara posisi kerja dengan keluhan sakit pada pekerja di masing-masing stasiun kerja menunjukkan bahwa, operator dengan kategori posisi kerja yang beresiko tinggi lebih dominan untuk mengalami keluhan sakit pada otot.

Pekerja melakukan tugasnya dengan posisi berjongkok, posisi jongkok tersebut tentu saja sudah termasuk dalam cara kerja yang salah. Dengan posisi kerja 
tersebut sudah jelas terlihat bahwa pekerja membentuk sudut yang besar dibagian kaki dengan nilai lebih dari $90^{\circ}$, apabila pekerja melakukan aktivitasnya dalam jangka waktu yang lama dengan posisi jongkok, maka bagian tubuh yang lain akan bisa terasa sakit dan rangka tulang lama kelamaan akan bisa berubah menjadi bungkuk. Akibatnya sudut yang terbentuk oleh tubuh menjadi tidak normal. Bagianbagian tubuh yang akan berubah besar sudutnya adalah pada bagian punggung dan kaki.

\section{Analisis Usulan Perbaikan Metode REBA}

Setelah melakukan perhitungan REBA dengan menggunakan lembaran worksheet untuk stasiun kerja pada proses pendempulan body. Dari masalahmasalah yang ada pada bagian pembuatan rumah boneka di Fatmawati Jakarta Selatan, maka didapatkan beberapa alternatif pemecahan masalah, yaitu :

a.Perbaikan posisi kerja dengan menggunakan meja dan kursi, ukuran yang digunakan sesuai dengan anthropometry pekerja.

Dengan menggunakan fasilitas kerja berupa meja dan kursi tersebut diharapkan para pekerja lebih mudah dalam melakukan aktivitas kerja yang berposisi jongkok. Sehingga dapat mengurangi keluhan rasa sakit pada bagian tubuh yang dialami pekerja.

b. Penempatan stasiun kerja yang harus diubah sesuai dengan luas tempat yang tersedia, sehingga para pekerja bisa bekerja dengan nyaman.

c. Diadakan tempat penyimpanan seperti gudang, untuk penyimpanan bahan baku dan sisa-sisa pemotongan bahan baku yang masih bisa dipergunakan kembali sehingga tidak berantakan pada area atau lokasi stasiun kerja.

\section{Hasil Perhitungan Perbaikan Postur Kerja}

Perhitungan perbaikan postur kerja yang dilakukan pada proses pendempulan. Sebelum melakukan perhitungan dengan menggunakan meja dan kursi, skor REBA yang didapatkan untuk masingmasing stasiun kerja rata-rata memiliki level resiko tinggi. Setelah melakukan perhitungan perbaikan postur kerja dengan menggunakan meja dan kursi, maka skor REBA yang didapatkan untuk masing-masing stasiun kerja rata-rata memiliki level resiko rendah. Perbandingan Skor REBA sebelum dan setelah perbaikan dapat dilihat pada tabel 8 dibawah ini. 


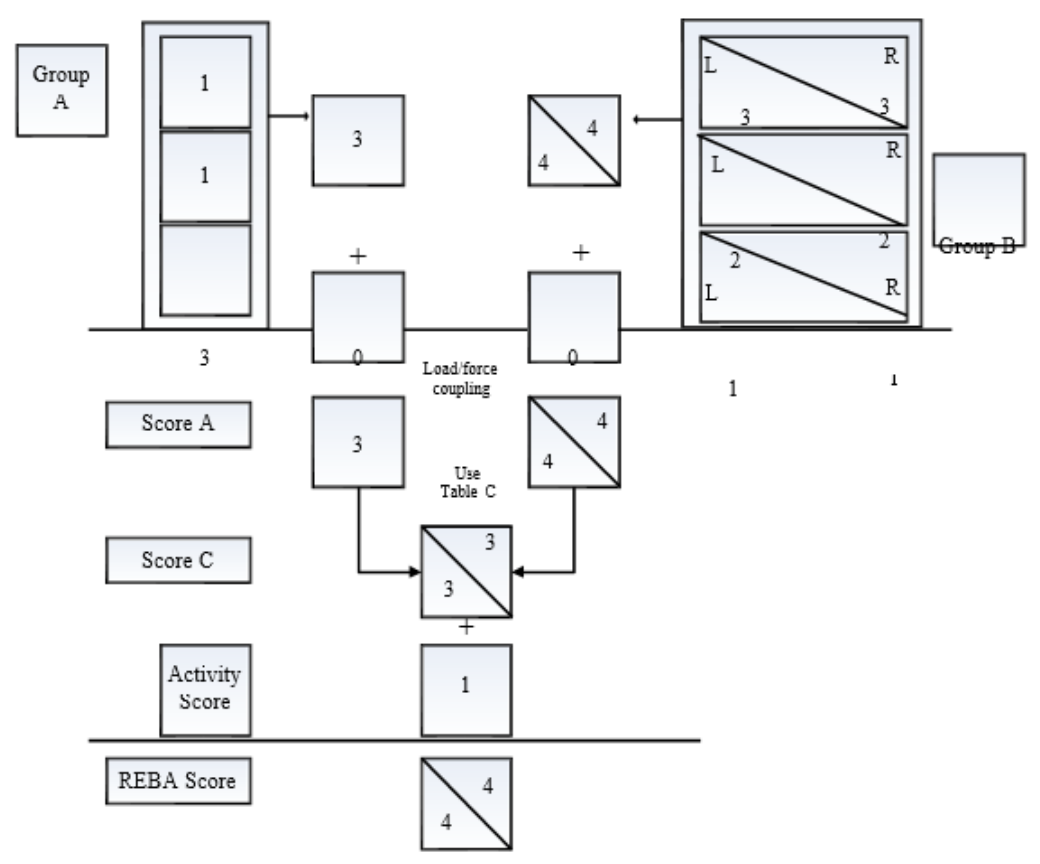

Gambar 8. Hasil Perhitungan Perbaikan Posisi Kerja Proses Pendempulan

Tabel 6. Perbandingan Skor REBA Sebelum Perbaikan dan Setelah Perbaikan

\begin{tabular}{|c|c|c|cr|}
\hline No & Stasiun Kerja & $\begin{array}{c}\text { Skor Reba Sebelum } \\
\text { Perbaikan }\end{array}$ & \multicolumn{1}{c|}{$\begin{array}{c}\text { Skor Reba Setelah } \\
\text { Perbaikan }\end{array}$} \\
\hline 1 & Pendempulan Body & 9 & 8 & 4 \\
\hline
\end{tabular}

Berdasarkan tabel 6 perhitungan REBA sebelum dan setelah perbaikan pada stasiun pendempulan skor REBA yang didapatkan stasiun kerja pendempulan body mendapatkan skor REBA untuk bagian kiri 9 dan untuk bagian kanan 8 , kedua bagian tersebut berada pada level resiko tinggi dan perlu tindakan perbaikan segera di bagian kaki dan punggung pekerja.

Setelah melakukan perhitungan perbaikan maka pada pendempulan body, kedua bagian mendapatkan nilai 4 dengan level resiko sedang dan perlu tindakan perbaikan.

\section{SIMPULAN DAN SARAN}

Berdasarkan hasil Nordic Questionaire dapat diketahui keluhan-keluhan apa saja yang dialami oleh pekerja, dan berdasarkan metode REBA dapat diketahui nilai-nilai dari setiap posisi kerja pada masingmasing operator. Pada proses pendempulan yang dilakukan dengan posisi jongkok dalam waktu yang cukup lama yaitu 30 menit akan beresiko menyebabkan pekerja cedera. Dengan adanya penambahan kursi dan meja kerja pada proses pendempulan dapat mengurngi resiko tersebut.

Untuk perbaikan selanjutnya perusahaan dapat merubah dan menambahkan aplikasi pada meja untuk bekerja, misalnya dengan pengaplikasian meja putar. Dengan begitu dapat mengurangi kelelahan dan meningkatkan produktivitas kerja.

\section{DAFTAR PUSTAKA}

[1] Hasibuan, M., Anizar, Arto, S. P. (2014). Analisis Keluhan Rasa Sakit Pekerja Dengan Menggunakan Metode REBA di Stasiun Penjemuran. E- 
Jurnal Teknik Industri FT USU Vol 1, No. 1, Februari 2014. PP. 18-22.

[2] Hendro, H., Imdam, I. A., Karina, R. I. Usulan Perancangan Fasilitas Kerja Dengan Pendekatan Ergonomi Menggunakan Metode Rapid Entire Body Assessmnet (REBA) di PT Z. Jurnal Riset Industri Vol. 10 No. 1, April 2016. hal. 1-11.

[3] Jalajuwita, R. N. \& Paskarini, I. Hubungan Posisi Kerja Dengan Keluhan Muskuloskeletal Pada Unit Pengelasan PT. X Bekasi. The Indonesian Journal of Occupational Safety and Health, vol. 4, no. 1 jan-jun 2015: 33-42.

[4] Joanda, A. D. \& Suhardi, B. Analisis Postur Kerja dengan Metode REBA untuk Mengurangi Resiko Cedera pada Operator Mesin Binding di PT. Solo Murni Boyolali. Seminar dan Konferensi Nasional IDEC 2017.

[5] Nur, R. F., Lestari, E. R., Mustaniroh, S. A. Analisis Postur Kerja pada Stasiun Pemanenan Tebu dengan Metode OWAS dan REBA, Studi Kasus di PG Kebon Agung, Malang. Industria: Jurnal Teknologi dan Manajemen Agroindustri. Volume 5 Nomor 1. 2016: 39-45.
[6] Nurhasanah, E., Mauluddin, Y. Perancangan Fasilitas Kerja yang Ergonomis dengan Pendekatan Rapid Entire Body Assessment pada Pekerja Home Industry Pembuatan Tempe. Jurnal Kalibrasi Sekolah Tinggi Teknologi Garut. Vol. 14 No. 12016.

[7] Restuputri, D. P., Lukman, M., Wibisono. Metode Reba untuk Pencegahan Musculoskeletal Disorder Tenaga Kerja. Jurnal Teknik Industri. Vol. 18, No. 01, Februari 2017, PP. 19 28.

[8] Rinawati, S., Romadona. Analisis Risiko Postur Kerja pada Pekerja Di Bagian Pemilahan dan Penimbangan Linen Kotor RS. X. Journal of Industrial Hygiene and Occupational Health. Vol. 1, No. 1, Oktober 2016.

[9] Sulaiman, F. \& Sari, Y. P. Analisis Postur Kerja Pekerja Proses Pengesahan Batu Akik Dengan Menggunakan Metode REBA. Jurnal Teknovasi. Volume 03, Nomor 1, 2016, 16-25. 